\title{
Identification Of Plasmodium Falciparum Merozoit Surface Protein-1 (Pfmsp-1) Gene From Malaria Patients In Hanura Area, Lampung, Indonesia
}

\author{
Ade Triajayanti ${ }^{1 *}$, Nurul Utami ${ }^{2}$, Betta Kurniawan ${ }^{3}$, Jhons Fatriyadi Suwandi ${ }^{3}$ \\ ${ }^{1}$ Student of Medical Program Study, Faculty of Medicine, University of Lampung \\ ${ }^{2}$ Department of Anatomy, Patology Anatomy and Histology, Faculty of Medicine, University of Lampung \\ ${ }^{3}$ Department of Microbiology and Parasitology, Faculty of Medicine, University of Lampung \\ *Corresponding Author E-mail: adetriaja@gmail.com
}

Received : August 15 2019

Accepted : October $28^{\text {th }} 2019$

\section{Background}

\section{ABSTRACT}

Malaria is a major health problem not only in Indonesia, but also the world. Incidence of anti malarial drug resistance has been found, and one of the possible cause is genetic factors. The changes that occur in the Plasmodium falciparum gene cause genetic variations that lead to resistance for treatment. There is a gene with high polymorphism that can be used as a gene marker of genetic variation in Plasmodium falciparum.

Objective

This study aim to identification of Plasmodium falciparum merozoit surface protein-1 (PFMSP-1) gene from malaria patients in Puskesmas Hanura, Pesawaran, Lampung. Methods

Descriptive method with morbidity survey approach is used in this study. There are total 23 biological material stored that had been taken in 2016 from malaria patient in Puskesmas Hanura, Pesawaran, Lampung, by consecutive sampling. Identification of genetic variance of the Plasmodium falciparum gene was performed by nested PCR at Medical Faculty Biomolecular Laboratory of Lampung University. The results of this study were processed using a computer software.

Results

There are 23 samples that amplified following nested PCR for Plasmodium falciparum Merozoit Surface Protein-1 (PFMSP-1) gene target. In all samples studied, there are PFMSP-1 gene with six variations base pair length range from 200 to $1000 \mathrm{bp}$.

Conclusions

The study has successfully amplified PFMSP-1 gene from individual's blood sample infected by Malaria in Puskesmas Hanura, Pesawaran, Lampung.

Keywords: Genetic variation, Hanura, Lampung, Plasmodium falciparum, PFMSP-1

\section{Introduction}

Malaria is one of the mosquito-borne disease that remains a major world health problem. In 2015, there are 212 million new cases worldwide. Estimated about 429.000 deaths in 2015, of which $92 \%$ were in WHO Afican region, $6 \%$ were in WHO South-East Asian region, and followed by $3 \%$ in WHO eastern Mediterranean region. Incidence rate of Malaria from 2010 to 
2015 has decreased about 21\%. ${ }^{1}$ Malaria is a burden that causing health problem in tropical region, specifically Indonesia. Annual Parasite Incidence (API) is a number of microscopically confirmed malaria cases detected during one year per 1000 individuals. In 2015, highest API were found in Papua, followed by West Papua, East Nusa Tenggara, Maluku, North Maluku, etc. Lampung is one of the endemic region of Malaria sat on 12th highest API provinces in Indonesia. $^{2}$ Lampung's Health Department stated that there are 26.722 cases of malaria with two deaths caused by Malaria occur in 2015. Highest Lampung's API were in Pesawaran district (6.36), followed by West Pesisir District (3.47) and Bandar Lampung $(0,58){ }^{3}$

Therapy given to patient with malaria are aims to kill and reduce parasitemia in the patient's body. This therapy uses anti-malarial drugs, but in some areas, resistance has been found to these treatments. ${ }^{4}$ The cause of resistance has begun to be widely studied and most studies say genetic factors are commonly cause the resistance. Genetically, a change in DNA structure can occur due to environmental stress or mutations. These changes of DNA stimulating changes of characteristic in previous genes, resulting in various genetic variations. In the case of malaria, the changes of DNA causing anti-malaria drugs unable kill the parasite, so that treatment is not successful ${ }^{5,6}$.

In Plasmodium falciparum, there are genes used as a marker for describing many biological processes like treatment failure, genetic diversity, transmition rate, multicon or multigenotip infection and immune response. Genes used as a marker for genetic diversity has the highest polymorphism level. There are three blocks of gene's location in Plasmodium falciparum which are conserved block, semiconserved block and block that placed in between. Gene that located in conserved and semiconserved block is the gene that its presences is preserved by these creatures, while the genes that located in between has the highest polymorphism level because of genetic mutation that increase genetic variation. One of the genes that have a high level of polymorphism in Plasmodium falciparum is the Plasmodium falciparum Merozoit Surface Protein-1 (PFMSP-1) gene. Based on several previous studies, the dominant allele of the PFMSP-1 gene found in Asia including Indonesia is MAD20. ${ }^{5,7,8}$ Based on this, this study will identify one gene, the PFMSP-1 gene specific to the MAD20 allele patient with malaria at Puksesmas (Central of Public Health Services) Hanura, Pesawaran, Lampung. 


\section{Methods}

This study is a quantitative research with descriptive survey method. The approach taken in this study is a morbidity survey to see the distribution of Plasmodium falciparum Merozoit Surface Protein-1 (PFMSP-1) gen. Subject of the research was biological material stored in the form of blood patient with malaria in the Puskesmas (Central of Public Health Services) Hanura area, Pesawaran, Lampung in 2016. Sampling began with collection data of patient with malaria in Puskesmas Hanura, Pesawaran, Lampung. Patient with malaria who have been received treatment are then given an explanation of the study and continued with informed consent. Patients who agreed to participate then would be taken blood test directly at the Puskesmas Hanura, Pesawaran, Lampung. The blood then placed in edta tube and each sample is given a sequential code label. Blood next would be sent to Parasitology Laboratory of Lampung University using a cool box which is stored in a refrigerator. This study was conducted at the Biomolecular Laboratory of Lampung University in August - December 2017.

Sample selection was using consecutive sampling which fit inclusion and exclusion criteria that have been determined. The inclusion criteria followed, sample can be used in PCR test and sample is sufficient in volume. Biological material stored with poor storage will be excluded. There are total 23 samples collected in this study.

This research was conducted in three stages, First DNA extraction, second DNA amplification (Nested PCR) and third electrophoresis. In the first stage, the blood patient with malaria was extracted using QIAamp® DNA Mini Kit (Qiagen). ${ }^{9}$ The DNA then would be amplified.

At the amplification stage the method used was nested PCR, which is carried out amplification process twice of sample under the study. Amplification stage used KAPA HiFi HotStart PCR Kit (Kapabiosystem) $)^{10}$ and MyFiTM DNA Polymerase (Bioline) ${ }^{11}$. The instrument used in the amplification stage is Rotor-Gene ${ }^{\circledR} \mathrm{Q}$ (Qiagen). The first stage amplification target is the PFMSP-1 gene and second amplification was MAD20 allele of the PFMSP-1 gene. The primers used in this study are accordant with primers published by Snounou and Färnet described in table one. The PCR conditions were $5 \mathrm{~min}$ at $95^{\circ} \mathrm{C}$ for predenaturation; $1 \mathrm{~min}$ at $94^{\circ} \mathrm{C}$ for denturation; $2 \mathrm{~min}$ at $58^{\circ} \mathrm{C}$ for anneling in first amplification and 2 min at $61^{\circ} \mathrm{C}$ for anneling in second amplification; $2 \mathrm{~min}$ at $72^{\circ} \mathrm{C}$ for extension; and $5 \mathrm{~min}$ at $72^{\circ} \mathrm{C}$ for final extention. ${ }^{12}$ During the PCR process, the condition was repeated 25 cycles (first amplification) 
and 30 cycles (second amplification) with the KAPA HiFi HotStart PCR Kit (Kapabiosystem). In MyFi TM DNA Polymerase (Bioline) it takes 30 cycles for both the first and the second amplification.

Table 1. Oligonucleated sequences (Primer)

\begin{tabular}{|c|c|}
\hline \multirow{2}{*}{\multicolumn{2}{|c|}{$\frac{\text { Reaction }}{\text { First reaction }}$}} \\
\hline & \\
\hline PFMSP-1 M1-OF & 5'- CTAGAAGCTTTAGAAGATGCAGTATTG -3' \\
\hline M1-OR & 5'- CTTAAATAGTATTCTAATTCAAGTGGATCA-3' \\
\hline Second reaction & \\
\hline $\begin{array}{l}\text { M1-MF } \\
\text { M1-MR }\end{array}$ & $\begin{array}{l}\text { 5'-AAATGAAGGAACAAGTGGAACAGCTGTTAC-3' } \\
\text { 5'-ATCTGAAGGATTTGTACGTCTTGAATTACC -3' }\end{array}$ \\
\hline
\end{tabular}

The amplification products were analyzed by electrophoresis on a 1\% agarose gel in 100 $\mathrm{V}, 50$ Watt and $250 \mathrm{mAh}$ for 55 minutes. The result then would be read under UV transilluminator. The identified PFMSP-1 gene is characterized by the presence of a band when reading process on the UV transilluminator. Genetic variations can be identified from the base length of each band found. The positive genetic variation is indicated by founding variety in the base length of each band.

The results of this study are numerical data (ratios) in the form of base lengths of each identified band. The distribution of PFMSP-1 gene was analyzed used computer software.

\section{Result}

There are total 23 samples of biological material stored successfully extracted resulting $200 \mu \mathrm{l}$ of volume for each sample. Those result then amplified following nested PCR methods. Identification of PFMSP-1 gene's base pairs length are used by using visualizations of the electrophoresis result under UV transiluminator. Visualizations results are shown in figure one. 


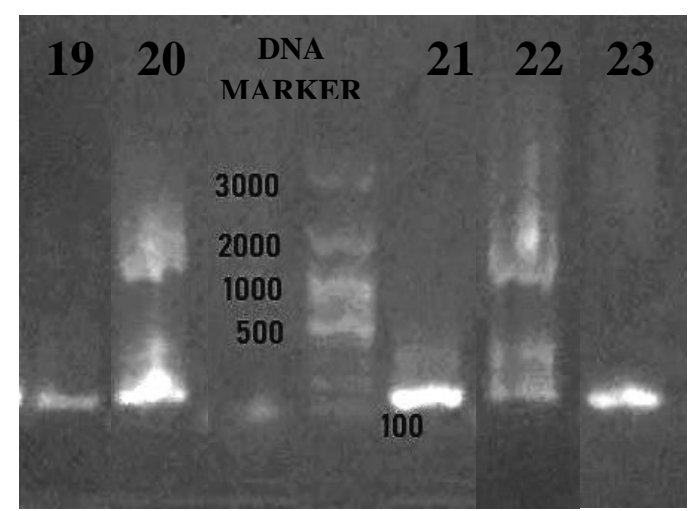

Figure 1. Electrophoresis result

Figure one is a visualization of a sample that has been on PCR. Band on each sample were visualized is MAD20 alleles of genes PFMSP-1 with a base pairs length corresponds to the length of DNA markers used. Figure one show that there are band on sample number 19 (200 bp), 20 (200 bp, 300 bp, 1000 bp), 21 (200 bp, 400 bp), 22 (200 bp, 400 bp, 1000 bp), dan 23 (200 bp). There are 28 bands identified out of 23 total samples with more than one band can identified in one. Four variaton of base pairs length were identified within range of 200-1000 bp, the majority of base pairs is 200 bp. Data base distribution that has been identified are explained in table three.

Table 3. Base Pairs Length Distribution

\begin{tabular}{cc}
\hline Base pairs length & Total Band \\
\hline $200 \mathrm{bp}$ & 20 \\
$300 \mathrm{bp}$ & 4 \\
$400 \mathrm{bp}$ & 2 \\
$1000 \mathrm{bp}$ & 2 \\
Total & $\mathbf{2 8}$ \\
\hline
\end{tabular}

\section{Discussion}

This study has successfully amplified PFMSP-1 gene (MAD20) from individual's blood sample infected by Malaria in Puskesmas Hanura, Pesawaran, Lampung. The PFMSP-1 gene in this study was positive found genetic variations with the results of four base pairs length variations identified in the range of 200-1000 bp, with $200 \mathrm{bp}$ become the most identified. This result is match with previous study conducted on four different hospital in South Sumaterea. Those study identified PFMSP-1 gene with nine gene's variations range from 175-600 bp. ${ }^{13}$

There are many Indonesia's provinces has been identified PFMSP-1 gene besides South Sumatera. Another study in West Sumatera, shows PFMSP-1 gene's (MAD20) base pairs length variation range from 110-360 bp. ${ }^{14}$ In East Indonesia region, Papua, shows PFMSP-1 gene's (MAD20) base pairs length variation from 106-255 bp. ${ }^{15}$ 
Identification result of PFMSP-1 gene in many regions in Indonesia shows gene's base pairs length variations are relatively similar. There are also studies conducted globally to identified PFMSP-1 gene with gene's base pairs length variations. There are Malaysia with PFMSP-1 gene's (MAD20) base pairs length variation range from 180 bp, Myanmar (120-300 bp), India (175-600 bp), Iran (170-210 bp with seven variations) and Ethiopia (100-300 bp). ${ }^{16-}$ 20

Based on the results of several studies that have been presented, the base pairs length variotion of PFMSP-1 gene with MAD20 alleles ranges from 100-600 bp. Based on this, this study supports data from previous studies and has been added in new literature regarding the variation in base pairs length of the MAD20 allele from the PFMSP-1 gene. In addition, this study is the first genetic data from the PFMSP-1 gene in the Pesawaran, Lampung, which is one of the malaria endemic areas.

Other previous study shows that PFMSP-1 gene is a gene with relatively high base pairs length variation proved by different range of base pairs length on each region. PFMSP-1 gene's base pairs length variation increase its genetic variations. Increase genetic variations is affected by characteristic of gene's itself and it's environment. Study conducted in Maluku, shows that there are seven base pairs length variations range from $100 \mathrm{bp}$ to $300 \mathrm{bp}$ in close community compared to 12 base pairs length variations range from $100 \mathrm{bp}$ to $500 \mathrm{bp}$ in open community. This difference shows that environmental factor can cause genetic variations. Close community defined as group of peoples that has minimal contact with environment and chemical substance such as drugs. Therefore, close community is less likely to have gene's mutation. Contrast to open community who expose with environmental factors such as interaction between individuals and other substances. ${ }^{18,20,21}$ The location of this research is one of the tourist locations in Lampung Province with a high intensity of tourist arrivals. This could be one of the factors of the high number of genetic variations in the Hanura region which support by the previous study.

Infection of more than one gene of Plasmodium sp. is called by multigenotipe infection. Multigenotip infections of Plasmodium falciparum can increase genetic variations in PFMSP1 gene and increase probability of gene recombination in meiotic state of Plasmodium sp. Recombination can occur in vector's body (Anopheles sp.) that bite individuals with multigenotype infection. Asexual phase of Plasmodium sp. occur in human body until gametocyte is formed, whether its macrogametocyte or microgametocyte. In this condition, Anopheles sp. probably takes up blood that contain gametocytes from different kind of Anopheles sp. genes. Meiotic recombination will occur at sexual phase in vector's body then 
causing new genetic variations. Proportion of multigenotype infection and amount of clones (Allelic types) per individual are two prerequisite that increase parasite genetic diversity..$^{13,18,21,22}$

In this study there are more than one variant of PFMSP-1 gene that infected one sample. This can occur as a result of multigenotip infection. Multigenotip infection can occur in a region with high level of transmission condition. This condition can increase interaction probability between another disease that occur in one individual. Location with high level of transmission often found in endemic region of Malaria. ${ }^{18,20}$ This study was conducted in Hanura, Pesawaran, Lampung, which is one of the malaria endemic areas with the highest Annual Parasite Incidence (API) in Lampung Province, $6.36 .{ }^{3}$ So with multigenotype infections that have been found and included in malaria endemic areas, the incidence of variation genetic makeup of the PFMSP-1 gene can be increased.

Along with increased genetic diversity in Plasmodium sp., changes will occur in parasite's body so it can adapt and survive its envionmental condition. One of genetic diversity effect is increased incidence of anti malaria drug resistance. This phenomenon is in line with study that conducted along west border of Thailand-Myanmar, found that there is lower cure rate of artesunate-mefloquine combination therapy in Ranong city compare to other city because of its high genetic diversity of PFMSP-1 gene. ${ }^{7}$ Furthermore, anti malarial drug (kloroquin) resistance also reported in India and Indonesia. ${ }^{23,24}$ The similarity of drugs resistance in Indonesia and India can be attributed by genetic factors of Plasmodium falciparum in both countries. Genetic similarity in a parasite stimulate the same response to administration of a substance, as same as treatment. So, it is necessary to conduct a strict data collection on the types of resistance that occur in each region that has genetic similarities in the parasite causing the disease, so that the incidence of resistance to a drug can be prevented or handled better.

Another factors that can increased genetic diversity of Plasmodium sp. are host, vector's population and its environment. Host of malaria is human's body, level of human immunity is the most substantial factor that affecting severity of the disease. The more higher level of immunity, defense mechanism of innate immunity against the parasite will also increase. The more higher vector's populations, transmission level and infection number of Plasmodium sp., will also increase. Environment as the last factor also has an important role because of its effect on enhancing another factors. ${ }^{13}$ 


\section{Conclusion}

PFMSP-1 gene has successfully amplified from individual's blood sample infected by Malaria in Puskesmas Hanura, Pesawaran, Lampung.

\section{Acknowledgment}

We are specifically grateful to Head of Lampung University and Dean of the Faculty of Medicine of Lampung University for the assistance given. We also thank all the volunteers who responded in this study; officers and staff of the Puskesmas Hanura, Pesawaran, Lampung, for their efforts in helping us reaching to the study sites and recruiting the volunteers; and Biomolecular Laboratoris Faculty of Medicine Lampung's University staff for their consultations on genotype and interpretation data.

\section{References}

1. World Health Organization (WHO). World Malaria Report 2016. Genewa: WHO; 2016.

2. Kementrian Kesehatan RI. InfoDatin Malaria. Jakarta: Pusat Data dan Informasi Kementerian Kesehatan RI; 2016.

3. Dinas Kesehatan Pemerintah Povinsi Lampung. Profil Provinsi Lampung Tahun 2015. Bandar Lampung: Dinas Kesehatan Pemerintah Povinsi Lampung; 2016.

4. Cui L, Mharakurwa S, Ndiaye D, Rathod PK, Rosenthal PJ. Antimalarial drug resistance: literature review and activities and findings of the ICEMR network. Am J Trop Med Hyg. 2015; 93(3):57-68.

5. Handayani S, Salwati E, Tjitra E. Keragaman Genetik Petanda P. Falciparum Dari Specimen Subyek Penelitian Monitoring Dihidroartemisinin-Piperakuin Di Kalimantan. Media Litbang Kesehatan. 2012; 22(3):120-130.

6. Simamora D, Fitri LE. 2007. Resistensi obat malaria: mekanisme dan peran obat kombinasi obat antimalaria. Jurnal kedokteran brawijaya. 23(2):82-91.

7. Congpuong K, Sukaram R, Prompan Y, Dornae A. Genetic diversity of the msp-1, msp-2, and glurp genes of $\mathrm{P}$ lasmodium falciparum isolates along the Thai-Myanmar borders. Asian Pac. J. Trop. Biomed. 2014; 4(8):598-602.

8. Mau F, Murhandarwati EEH. Keragaman Genetik dari Msp 1, Msp 2, dan Glurp pada Plasmodium Falciparum di Kabupaten Sumba Tengah, Nusa Tenggara Timur. Buletin Penelitian Kesehatan. 2016; 44(2):77-84.

9. Qiagen. QIAamp DNA mini and blood mini handbook. Edisi Ke-5. Hilden: Qiagen; 2016.

10. Kapabiosystem. KAPA HiFi HotStart technical data sheet. Boston: Kapabiosystem; 2013.

11. Bioline. MyFi DNA polymerase. Singapore: Bioline; 2017.

12. Snounou G, Färnet A. Genotyping of Plasmodium falciparum parasites. Dalam: Moll K, Kaneko A, Scherf A, Wahlgren M. Methods in malaria research. Edisi ke-6. UK: EVIMalar Glasgow; 2013.

13. Handayani D, Nindela R, Saleh I. Genetic diversity of merozoite surface protein 1 (MSP 1) in Plasmodium falciparum dield isolates from South Sumatera. Bandung International Scientific Meeting on Parasitology and Tropical Disease 2015; 2015 Mei 2; Bandung. Indonesia: BISMPTD; 2015.

14. Irawati N. Genetic polymorphism of merozoite surface protein-1 ( MSP-1) block 2 allelic types in Plasmodium falciparum fi eld isolates from mountain and coastal area in West Sumatera, Indonesia. Med J Indones. 2011;20:11-14. 
15. Sorontou Y, Pakpahan A. Genetic diversity in MSP-1 gene of Plasmodium falciparum and its association with malaria severity, parasite density, and host factors of asymptomatic and symptomatic patients in Papua, Indonesia. Int. J. Med. Sci. Public Heal. 2015; 4(11):158493.

16. Razak, M. R. M. A. et al. Genetic diversity of plasmodium falciparum populations in malaria declining areas of Sabah, East Malaysia. PLoS One 11, 1-22 (2016)

17. Soe TN, Wu Y, Tun MW, Xu X, Ruan Y, Win AYN, et al. Genetic diversity of Plasmodium falciparum populations in Southeast and Western Myanmar. Parasites \& Vectors. 2017; 10(322):1-6.

18. Hussain MM, Sohail M, Kumar R, Branch OH, Adak T, Raziuddin M. Genetic diversity in merozoite surface protein-1 and 2 among Plasmodium falciparum isolates from malarious districts of tribal dominant state of Jharkhand, India. Annals of tropical medicine and parasitology. 2011; 105(8):579-92.

19. Adel E, Tahareh D. Malaria Chemotherapy Control \& Elimination Genetic Diversity of Variable Region Block 2 in the Merozoite Surface Protein-1 ( MSP1 ) in Plasmodium falciparum Field Isolates from South-East of Iran. 2014; 3(2):1-4.

20. Mohammed H, Mindaye T, Belayneh M, Kassa M, Assefa A, Tadesse M, et al. Genetic diversity of Plasmodium falciparum isolates based on MSP-1 and MSP-2 genes from Kolla-Shele area, Arbaminch Zuria district, Southwest Ethiopia. Malaria Journal. 2015; 14(73):1-7.

21. Sillehu S, Arwati H, Dachlan YP, Keman S. Genetic Polymorphism of Plasmodium Falciparum Merozoite Surface Protein-1 ( Pfmsp-1 ) in Closed and Opened Community at South Buru District, Maluku Province. Dama Int. J. Res. 2016; 1(9):1-4.

22. Kang JM, Moon SU, Kim JY, Cho SH, Lin K, Sohn WM, et al. Genetic polymorphism of merozoite surface protein-1 and merozoite surface protein-2 in Plasmodium falciparum field isolates from Myanmar. Malaria Journal. 2010; 9(131):1-8.

23. Shah NK, Dhillon GPS, Das AP, Arora U, Meshnick SR, Valecha N. Antimalarial drug resistance of Plasmodium falciparum in India: changes over time and space. Lancet Infect Dis. 2015; 11(1):57-64.

24. Elyazar IRF, Hay SI, Baird JK. Malaria distribusion, prevalence, drug resistance and control in Indonesia. Adv Parasitol. 2011; 74(1):41-175. 